\title{
Investigation of the Relationship Between Quality of Work Life, Burnout and Spiritual Well-being in Intensive Care Nurses
}

\author{
Yoğun Bakım Hemşirelerinde İş Yaşam Kalitesi, Tükenmişlik ve Spiritüel İyi Oluş \\ Arasındaki İlişkinin İncelenmesi
}

Mustafa DURMUŞ ${ }^{1}$, Halil ALKAN ${ }^{2}$

\begin{abstract}
This study was conducted as a descriptive study to determine the relationship between quality of work life, burnout and spiritual well-being in intensive care nurses. The research has been carried out on 211 nurses who work in the intensive care units in three public hospitals located in Turkey's Eastern Anatolia Region. In data collection, a form containing questions about the socio-demographic characteristics of individuals (age, gender, education level, marital status, economic status and receiving spiritual care education), "Spiritual Well-being Scale", "Nursing Work Life Scale" and "Maslach Burnout Scale" were used. $\mathrm{T}$ test was used for independent variables in the analysis of the data. In addition, the effect of independent variables on the dependent variable in numerical data was made using multiple regression analysis. In this study, it was determined that the spiritual well-being and emotional exhaustion levels of the nurses were above the middle level, and the mean scores of the nurses' quality of life, depersonalization and personal accomplishment were below the middle level. As a result, it was found that as the spiritual well-being levels of nurses working in intensive care increased, their burnout levels decreased and their work life quality increased. In addition, it was found that nurses who received spiritual care training had higher work life quality and lower burnout levels than nurses who did not receive training.
\end{abstract}

Keywords: Burnout, Intensive care, Nurse, Spiritual well-being, Quality of life.

\section{ÖZ}

$\mathrm{Bu}$ çalışma yoğun bakım hemşirelerinde iş yaşam kalitesi, tükenmişlik ve spiritüel iyi oluş arasındaki ilişkiyi belirlemek amacıyla tanımlayıcı olarak yapıldı. Araştırma Türkiye'nin Doğu Anadolu Bölgesinde yer alan üç devlet hastanesinin yoğun bakım ünitelerinde çalışan 211 hemşire ile gerçekleştirildi. Veri toplamada bireylerin sosyo-demografik özelliklerine (yaş, cinsiyet, eğitim düzeyi, medeni durum, ekonomik durum ve manevi bakım eğitimi alma) ait soruları içeren bir form, "Spiritüel İyi Oluş Ölçeği”, "Hemşirelik İş Yaşamı Kalitesi Ölçeği”" ve "Maslach Tükenmişlik Ölçeği” kullanılmıştır. Verilerin analizinde bağımsız değişkenlerde $\mathrm{T}$ testinin yanı sıra; sayısal verilerde bağımsız değişkenlerin bağımlı değişken üzerine etkisi çoklu regresyon analizi kullanılarak yapıldı. $\mathrm{Bu}$ çalışmada hemşirelerin spiritüel iyi oluş ile duygusal tükenme düzeylerinin orta seviyenin üstünde, hemşirelerin yaşam kaliteleri, duyarsızlaşma ve kişisel başarıda düşme hissi puan ortalamalarının orta düzeyin altında olduğu saptanmıştır. Sonuç olarak yoğun bakımda çalışan hemşirelerin spiritüel iyi oluş düzeyleri arttıkça tükenmişlik düzeylerinin azaldığı ve iş yaşam kalitelerinin $\operatorname{arttığı~bulunmuştur.~Ayrıca~spiritüel~}$ bakım eğitimi alan hemşirelerin eğitim almayan hemşirelerden daha yüksek iş yaşam kalitesine ve daha düşük tükenmişlik düzeyine sahip oldukları saptanmıştır.

Anahtar Kelimeler: Hemşire, Manevi iyi oluş, Tükenmişlik, Yaşam kalitesi, Yoğun bakım.

\footnotetext{
Approval was obtained from Ethics Committee for the study (Number: E-10879717-050.01.04-11762).

${ }^{1}$ Dr. Öğretim Üyesi, Mustafa DURMUȘ, Hemşirelik, Department of Gerontology, Faculty of Health Sciences, Muș Alparslan University 49100, Muş/Turkey, saremeryem01@gmail.com, ORCID: 0000-0002-7559-4187

${ }^{2}$ Dr. Ögretim Üyesi, Halil ALKAN, Fizyoterapi ve Rehabilitasyon, Department of Physiotherapy and Rehabilitation Faculty of Health Sciences Mus Alparslan University, 49100, Muş/Turkey ORCID: 0000-0001-6895-2495
} 


\section{INTRODUCTION}

In the intensive care unit (ICU), treatment of life-threatening diseases and care of patients exposed to these diseases are provided. In these units, the primary goal is to provide supportive treatments for critical patients who have problems with vital signs and therefore require treatment, and to ensure that these patients are not affected by adverse situations or are affected as little as possible. ${ }^{1,2}$ Therefore, the service provided in these units requires a multidisciplinary approach. In addition to being equipped with ICU high-tech devices, the healthcare personnel working here are trained about these units. ICU nurses are also one of the most important and critical members of this team. ${ }^{1,3}$

ICU nurses are tasked with diagnosing patients in these units, continuously monitoring patients, establishing therapeutic relationships with patients and their relatives, applying quality and advanced intensive care and treatment interventions, and implementing remedial, protective and rehabilitative interventions. In addition, ICU nursing is a health field that requires very special practices and training. ${ }^{4}$

Quality of work life is one of the issues addressed to make nurses happier and more productive in the work environment, and it is a work environment where employees are satisfied with the way they are managed. The adoption of the institution and the presence of a sense of belonging increase the liking of the job, job satisfaction, job motivation and work commitment. On the contrary, negative conditions in working conditions can lead to a decrease in productivity, economic loss of the institution, and job dissatisfaction, leading to a decrease in the quality of patient care. ${ }^{5,6}$

The service provided in the ICU differs from other working environments with its unique structure mentioned above. As a result, people working in the ICU have more work-related stress factors, which paves the way for employees to experience more work stress and burnout. ${ }^{7}$ When looking at the studies on nurses related to the subject; Stress factors in nurses are listed as caring for critically ill patients, frequent encounters with death, working with complex tools, conflict with management. ${ }^{7-9}$ With the combination of these factors, mental disorders can potentially occur in ICU nurses due to high stress and unfavorable working conditions. ${ }^{10}$

Although spiritual well-being is a concept that shows the essence of the existence and purpose of existence of people, the awareness of the factors that affect the life styles of individuals, create a sense of self, give the meaning of life, and what their inner resources are the factors that shape life, ${ }^{11}$ it is a process that involves harmony within the mind, body and soul. ${ }^{12}$ In other words, it is expressed as a situation that combines biopsychosocial components. ${ }^{13}$

Nursing and spiritual need is a discipline and field of research in which different psychological theories and methods are applied to examine human belief and behavior. ${ }^{14}$ Coyle states that spiritual wellbeing creates a positive frame of mind that leads to meaning and purpose, healthy behavior. ${ }^{15}$ Spiritual benefits of spiritual well-being are listed as less anxiety and depression, more peace, sense of hope and optimism, more purpose and meaning, higher social support, and higher marital satisfaction. ${ }^{16}$ With the strengthening of the spiritual dimension, the spiritual needs of the ability to experience and integrate the meaning and purpose of life can be met. ${ }^{17}$

When the literature is reviewed, studies on intensive care nurses show job satisfaction, burnout quality of work life and mental state closely associated with work stress are discussed separately. ${ }^{6-8,10}$ However, there is no study examining the relationship between work life quality, burnout and spiritual wellbeing in intensive care nurses. The aim of this study is to reveal the relationship between work life quality, burnout and spiritual well-being in intensive care nurses. 


\section{MATERIALS AND METHODS}

\section{Type of the Research}

The research was done in a cross-sectional and descriptive type.

\section{Place and Time of the Research}

Research was carried out between 13.10.2020-13.11.2020 on nurses who are working in the intensive care units of three public hospitals located in the Eastern Anatolia region of Turkey.

\section{The Population and Sample of the Research}

The population of this research consists of nurses actively working (6.56 \pm 2.29 years) in three public hospitals located in the Eastern Anatolia Region of Turkey. The research sample was calculated as 200 nurses at $95 \%$ confidence interval $^{18}$, and it was completed with 211 nurses.

\section{Personal Information Form}

The personal information form prepared by the researcher (including age, gender, education level, marital status, economic status, and the status of receiving spiritual care education) consists of 6 questions.

\section{Spiritual Well-Being Scale}

It is a 5-point Likert-type self-assessment scale developed by Ekşi and Kardaş to measure spiritual well-being. Scale items; it is evaluated between 1 "not suitable for me" and 5 "completely suitable for me". Items 1 , $4,5,8,9,12,13,16,17,20,21,24,25,27$, 29 measure transcendence sub-dimension; Items 2，6，10，14，18，22，28 measure harmony with nature sub-dimension; Items 3 , $7,11,15,19,23,26$ measure the anomie subdimension. When a total score is to be calculated, items in the anomie subdimension are scored in reverse. Subdimension scores are obtained by the total score of the answers given to the items in that sub-dimension; The total spiritual well-being score is obtained by the sum of the subdimension scores and ranges between 29 and 145 points. Higher scores indicate higher overall spiritual well-being. ${ }^{19}$

\section{Nursing Work Life Quality Scale}

It was developed by Brooks (2001) to measure the quality of work life of nurses. ${ }^{20}$ The validity and reliability study of the Turkish form of the Nursing Work Life Scale was conducted by Şirin (2011), and the reliability of the scale was evaluated with the Cronbach Alpha coefficient and item-total score correlation. As a result of the item-total score correlation analysis, 7 items (items 10, $13,27,29,30,36$ and 37) were removed from the scale. The Turkish version of the Nursing Work Life Scale is graded in a 5point Likert-type ( $1=$ strongly disagree, $2=$ disagree, 3 = indecisive, $4=$ agree, $5=$ strongly agree). In calculating the scale score, items 3, 10, 14 and 18 are reverse scored. The lowest total score that can be obtained from the scale is 35 , and the highest total score is 175. Accordingly, the increase in the total score that can be obtained from the scale indicates that the quality of work life of the nurses is high, and the decrease in the total score indicates that the quality of work life of the nurses is low. The Cronbach Alpha coefficient of the Nursing Work Life Scale, which consists of 35 items and 5 subdimensions, was determined as 0.89 . Cronbach's alpha coefficients for the subdimensions are $\alpha=0.78$ for the "job / working conditions" sub-dimension, $\alpha=0.81$ for the "relations with managers" subdimension, $\alpha=0.71$ for the "work conditions" sub-dimension. perception "subdimension and $\alpha=0,62$ for" support services" sub-dimension. ${ }^{21}$

\section{Maslach Burnout Scale}

Developed by Maslach and Jackson, The Maslach Burnout Scale (MBI), was adapted to Turkish by Ergin and its validity and reliability were tested at the same time. ${ }^{22,23}$ MBI has 3 sub-dimensions: "emotional exhaustion", "depersonalization" and "feeling of falling in personal accomplishment". Emotional exhaustion consists of 9 items (1, $2,3,6,8,13,14,16,20)$ that define the feelings of being consumed and overloaded 
by the work of the person, and includes negative expressions, and higher scores from these items indicate more emotional exhaustion while the score range is between 0 and 36. Depersonalization consists of 5 items $(5,10,11,15,22)$, which defines the individuals' behavior towards the ones they serve in a manner that is devoid of emotion and regardless of the fact that they are a unique entity, and includes negative statements, and the higher scores to be obtained from these items indicate that there is more depersonalization. The score range is $0-20$. The feeling of falling in personal accomplishment consists of 8 items $(4,7,9$, $12,17,18,19,21)$ that define the feelings of competence and success in people working with people, it contains positive expressions and is reverse-coded, so the higher scores to be obtained show a decrease in personal accomplishment. The scale consists of 22 items and is a five-point Likert-type scale (scoring from 0 to 4 ). For each item, one of the 5 options (never-very rare-sometimesoften-always) should be answered. "Never" option is evaluated by giving 0 points and "Always" option with 4 points. The score calculation changes because MBI has subdimensions and measures different situations. Emotional exhaustion total score ranges (0$36)$, depersonalization total score ranges (020 ), and personal accomplishment total score ranges $(0-32){ }^{23}$

\section{Collection of Data}

The nurses were informed by online about the study, before the link address (https://forms.gle/uhi6oTR3DHSWGTbt7) of the study was sent via e-mail to the individuals who accepted the study. In collecting data, questions about sociodemographic characteristics of individuals, "Spiritual Well-Being Scale", "Nursing Work Quality Scale" and "Maslach Burnout Scale" were used.

\section{Evaluation of Data}

Statistical analysis was done using "IBM® SPSS (C 24 software". The suitability of variables to normal distribution was examined using visual (histogram and probability graphs) and analytical methods (Kolmogorov-Smirnov).Descriptive statistics of numerical variables were expressed as mean and standard deviation. Descriptive statistics of categorical variables were given using number and percentage values. T-test was used for independent variables to compare two independent groups with normal distribution. In numerical data, the effect of independent variables on the dependent variable was performed using multiple regression analysis. During the multiple regression analysis, assumptions such as linear relationship between variables, extreme values, multicollinearity, normal distribution of prediction errors were taken into account. The statistical significance level was accepted as $\mathrm{p}<0.05$.

\section{Ethical Aspect of the Research}

Ethical approval was obtained for study (Number: E-10879717-050.01.04-11762). Online permissions were obtained from the individuals participating in the study, by giving information about the purpose of the research, the method, the time they would spend for the research, that participating in the study would not do any harm and that the participation was completely voluntary.

\section{Limitations of the Study}

The limitations of this study are that it was initiated during the pandemic period, and conducted online. A limitation of this study is that this study was performed only in hospitals in the east of our country and that other regions could not be included due to the limitation of possibilities.

\section{Funding}

This research did not receive any specific grant from funding agencies in the public, commercial, or not-for-profit sectors.

\section{Declaration of Competing Interest}

The authors declare no conflict of interest in this study.

\section{Acknowledgements}

The authors wish to thank and acknowledge the participants for sharing their experiences with us. 


\section{RESULTS AND DISCUSSION}

The statistical results of the analyzes made in this section are given in tables. The variables belonging to the numerical and categorical data of the nurses included in the study are given in Table 1.

Table 1. Features of Numerical and Categorical Data of The Nurses Íncluded in The Study

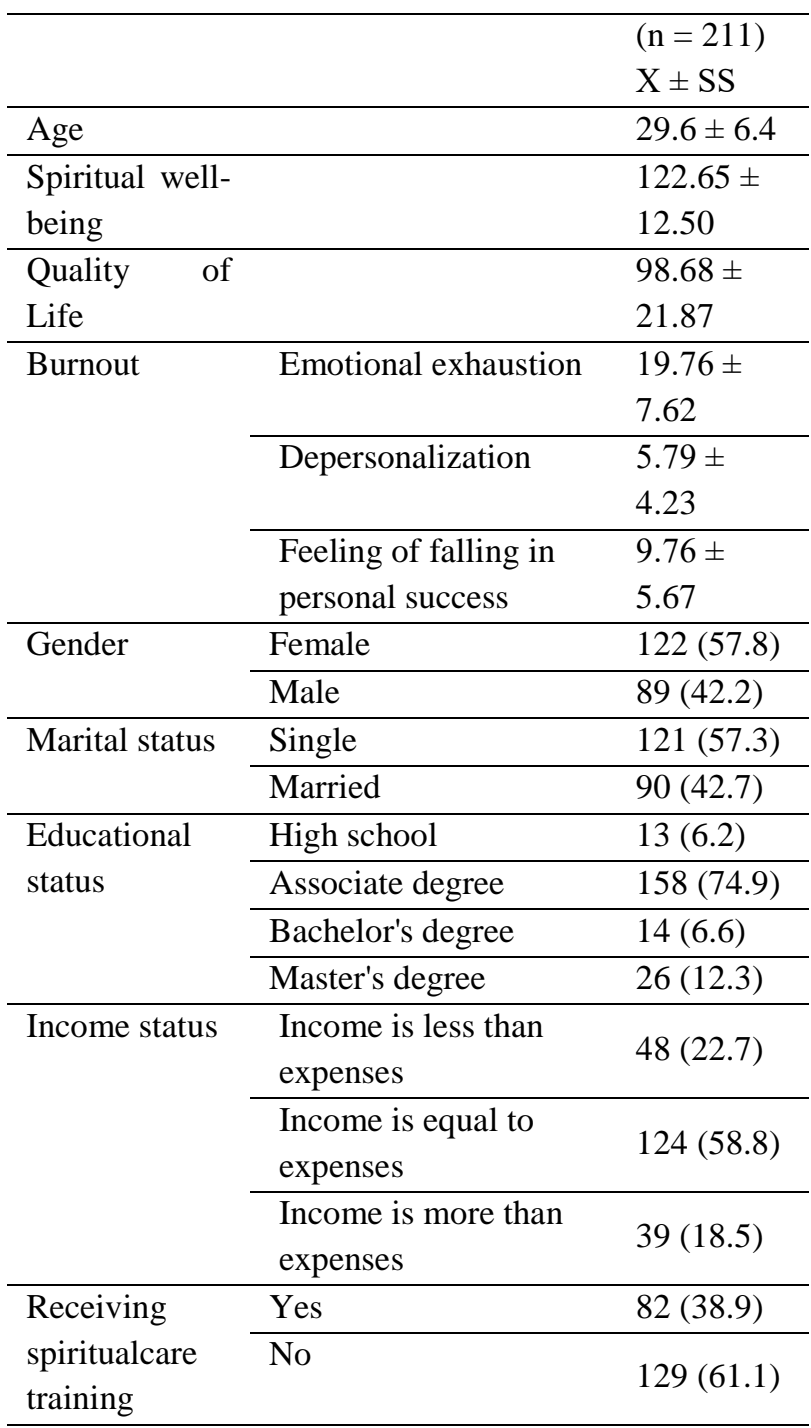

$\mathrm{X} ;$ mean, SS; Standard deviation

In this study, the spiritual well-being levels of nurses $(122.65 \pm 12.50)$ were above the medium level, their quality of life $(98.68$ \pm 21.87 ) was below the medium level, and emotional exhaustion (19.76 \pm 7.62) was above the medium level, depersonalization $(5.79 \pm 4.23)$ and the feeling of falling in personal accomplishment $(9.76 \pm 5.67)$ were found to be below the middle level (Table 2).
Table 2. Comparison of Work Life Quality and Burnout Levels of The Nurses Included in The Study According To Their Spiritual Care Training Status

\begin{tabular}{|c|c|c|c|c|}
\hline & & $\begin{array}{l}\text { Receiving } \\
\text { training }\end{array}$ & spiritual care & \\
\hline & & & & $\mathrm{p}$ \\
\hline & & $(\mathrm{n}=82)$ & $(n=129)$ & \\
\hline & & $\mathrm{X} \pm \mathrm{SS}$ & $\mathrm{X} \pm \mathrm{SS}$ & \\
\hline \multirow{6}{*}{ 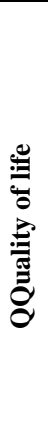 } & $\begin{array}{l}\text { Working } \\
\text { environment }\end{array}$ & $28.87 \pm 6.03$ & $26.23 \pm 5.67$ & $0.002 * *$ \\
\hline & $\begin{array}{l}\text { Relations with } \\
\text { the manager }\end{array}$ & $13.30 \pm 3.64$ & $12.39 \pm 3.19$ & 0.056 \\
\hline & Work conditions & $28.16 \pm 7.41$ & $25.88 \pm 6.63$ & $\mathbf{0 , 0 2 1} *$ \\
\hline & $\begin{array}{l}\text { Business } \\
\text { perception }\end{array}$ & $22.74 \pm 5.52$ & $19.43 \pm 5.37$ & $\mathbf{0 . 0 0 0} * *$ \\
\hline & Support services & $12.10 \pm 3.03$ & $10.61 \pm 2.88$ & $\mathbf{0 . 0 0 0} * *$ \\
\hline & Total & $105.17 \pm 22.67$ & $94.55 \pm 20.37$ & $0.001 * *$ \\
\hline \multirow{3}{*}{$\stackrel{\Xi}{\Xi}$} & $\begin{array}{l}\text { Emotional } \\
\text { exhaustion }\end{array}$ & $18.09 \pm 7.80$ & $20.87 \pm 7.32$ & 0.012* \\
\hline & Depersonalization & $5.49 \pm 3.89$ & $5.99 \pm 4.45$ & 0.416 \\
\hline & $\begin{array}{l}\text { Feeling of falling } \\
\text { in personal } \\
\text { success }\end{array}$ & $9.05 \pm 5.91$ & $10.24 \pm 5.48$ & 0.152 \\
\hline
\end{tabular}

T Test for independent variables, *; $\mathrm{p}<0.05$, **; p0.01, X; mean, SS; Standard deviation

When the quality of work life is compared according to the spiritual education status of the nurses, except for "relations with the manager" sub-dimension, which is one of the sub-dimensions of work life quality, there was a statistically significant difference in all sub-dimensions ( $p<0.05$ ). According to this result, it was observed that the quality of work life (work / working environment, job perception, support services, total score) of the nurses who received training on spiritual issues were higher than the nurses who did not receive training (Table 2 ).

When the burnout levels of the nurses are compared according to their spiritual care training, a statistical difference was found in the burnout levels regarding the subdimension "emotional exhaustion" $(p<0.05)$; while no difference was found in other subdimensions ( $p>0.05$ ) (Table 2). According to this result, it was observed that the burnout 
levels (emotional exhaustion) of the nurses who received training on spiritual issues were lower than the nurses who did not receive training.

Table 3. Examining The Work Life Quality of The Nurses Included in The Study in Terms of Spiritual Well-Being and Burnout

\begin{tabular}{|c|c|c|c|c|c|}
\hline & $\Delta \mathrm{R}^{2}$ & $\mathrm{~F}$ & $\beta$ & $t$ & $\mathrm{p}$ \\
\hline & 0.452 & 41.044 & & & $<0.001$ \\
\hline \multicolumn{6}{|c|}{ Spiritual well-being } \\
\hline & & & .131 & .363 & 0.019* \\
\hline \multirow{5}{*}{ 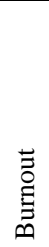 } & Emotional & & & & 0.000* \\
\hline & exhaustion & & 0.624 & 9.164 & $*$ \\
\hline & Depersonalization & & .091 & .319 & 0.189 \\
\hline & Feeling of falling & & & & 0.001* \\
\hline & in personal success & & 0.195 & 3.456 & $*$ \\
\hline
\end{tabular}

In the model we created according to multiple regression analysis, it was found that independent variables have an effect on the quality of work life of nurses $\left(\Delta \mathrm{R}^{2}=45.2\right.$, $\mathrm{p}<0.001)$. Considering the effects of these variables on the quality of work life of nurses; While the variables of "emotional exhaustion" and "feeling of falling in personal accomplishment", which are subdimensions of spiritual well-being and burnout, had a statistically significant effect ( $p<0.05$ ); It was observed that the burnout "depersonalization" sub-dimension had no statistical effect ( $p>0.05)$. When the effects of statistically significant variables on the quality of work life of nurses are compared in terms of size, it's observed as the following; respectively "emotional exhaustion" ( $\beta=0.624, p=0.000)$, "feeling of falling in personal accomplishment" $(\beta=$ $0.195, \mathrm{p}=0.001)$ and spiritual well-being $(\beta$ $=0.131, \mathrm{p}=0.019)($ Table 3$)$.

When these test results were examined more clearly, it was observed that the quality of work life of nurses increased as the scores of "spiritual well-being" increased, and the scores of "emotional exhaustion" and "feeling of falling in personal accomplishment" decreased. In addition, the "emotional exhaustion" sub-dimension was found to have a greater effect on nurses' work life quality than other variables (Table 3 ).
Table 4. The Effect of Burnout Level of ICU Nurses Included in The Study in Terms of Spiritual Well-Being

\begin{tabular}{|c|c|c|c|c|c|}
\hline & $\Delta \mathrm{R}^{2}$ & $\mathrm{~F}$ & $\beta$ & $\mathrm{t}$ & $p$ \\
\hline & 0.071 & 5.925 & & & 0.001 \\
\hline \multirow[t]{3}{*}{ Burnout } & $\begin{array}{l}\text { Emotional } \\
\text { exhaustion }\end{array}$ & & .106 & 9.164 & 0.233 \\
\hline & $\begin{array}{l}\text { Depersonalizati } \\
\text { on }\end{array}$ & & 0.038 & .319 & 0.671 \\
\hline & $\begin{array}{l}\text { Feeling of } \\
\text { falling in } \\
\text { personal success }\end{array}$ & & $\begin{array}{l}- \\
- \\
0.230\end{array}$ & 3.456 & $0.002 *$ \\
\hline
\end{tabular}

In the model we created according to multiple regression analysis, it was found that the burnout level of ICU nurses has an effect on spiritual well-being $\left(\Delta \mathrm{R}^{2}=0.071, \mathrm{p}\right.$ $<0.01$ ). While the variables of "feeling of falling in personal accomplishment", one of the burnout sub-dimensions, had a statistically significant effect ( $\mathrm{p}<0.05)$; It was observed that other sub-dimensions had no statistical effect ( $p>0.05)$. When these test results were examined more clearly, it was observed that as the burnout level of the nurses decreased, their "spiritual well-being" scores increased (Table 4).

In this study, which was carried out to examine the relationship between work life quality, burnout and spiritual well-being in intensive care nurses, it was observed that the quality of work life increased as nurses' "spiritual well-being" scores increased and their burnout sub-dimensions "feeling of personal accomplishment" and "emotional exhaustion" decreased. In addition, the quality of work life (working environment, work perception, support services, total score) of nurses who receive spiritual care training is higher than nurses who do not receive training, and the burnout levels (emotional exhaustion) of nurses who receive spiritual care training are lower than nurses who do not receive training.

In this study, it was determined that the quality of life of nurses was below the medium level, emotional exhaustion was above the medium level, and the sense of 
depersonalization and feeling of falling in personal accomplishment was below the medium level.

Similar results have been obtained in some studies regarding the emotional burnout levels of nurses. ${ }^{24,25}$ In the studies Yildirım and Hacihasanoğlu (2011) carried out with healthcare workers and Kavlu and Pinar (2009) carried out with nurses, it was found that individuals' quality of life was moderate. ${ }^{26,27}$ It is thought that factors such as the caregiver burden on nurses during the COVID-19 outbreak process and the work done during the COVID-19 outbreak are the factors that make the result different from the studies conducted.

Coyle and others express spiritual wellbeing as a positive frame of mind that leads to healthy behavior. ${ }^{15}$ Studies show the spiritual benefits of spiritual well-being such as less anxiety and depression, more peace, a sense of hope and optimism, more purpose and meaning, higher social support, and higher marital satisfaction. ${ }^{16}$ In a study conducted by Bae et al. on 131 emergency service nurses, it was shown that nurses' spiritual well-being has positively affected the quality of life of nurses. ${ }^{28}$ Similarly, in another study conducted on 93 nurses working in the hospital regardless of the clinical service, a positive relationship was found between spiritual well-being and nurses' quality of life. ${ }^{29}$ In the literature, only the above studies have been found that examine the relationship between nurses' mental well-being and quality of life. Similar to the results of these studies, it was observed in this study that as the spiritual well-being scores increased, the quality of life of nurses also increased. The difference of this study from the above studies is that the study being conducted on nurses working in the ICU where stress factors and burnout are higher ${ }^{7}$ and it evaluating their quality of work life are among the strengths of this study.

As it is stated that the spiritual care practices of nurses may have a special effect on patients ${ }^{30}$; it is also emphasized that it will help the patients gain motivating, relaxing, different perspectives. $^{31}$ There are studies that show that spiritual care practices on the elderly has positive results such as being physically more healthy, lesser alcohol consumption, lower risk of stroke, lower blood pressure, longer life, lower stress levels, and better quality of life. ${ }^{32-34}$ In addition to these studies, many studies on people with different diseases reported that low spiritual well-being is a risk factor for anxiety and depression. ${ }^{35,36}$ Thus, it's observed there are a lot of benefits of the spiritual care practises that these individuals possess for patients. One of the research questions in this study was to investigate whether receiving spiritual care training has an effect on work life quality and burnout in ICU nurses. In this study, it was found that ICU nurses who received spiritual care training had higher work life quality scores, while their burnout levels were lower than nurses who did not receive spiritual care training. One of the strengths of this study is that there are no studies on spiritual care training, quality of work life and nurses' burnout level. In the light of these findings, we can say that receiving spiritual care training and spiritual care practices are effective not only for the patients and the elderly, but also for the ICU nurses to create better quality of work life and lower burnout levels. In this study, we found that as the burnout of ICU nurses increases, their work life quality decreases.

Burnout is a state of physical, mental and mental energy deficiency that is characterized by the formation of a chronic negative self after a chronic period of continuous work-related stress, feelings of fatigue and hopelessness, negative attitudes towards work life and other people. ${ }^{27}$ When looking at the studies examining the relationship between the work life quality of nurses and burnout, Karagöz found that there is a significant negative relationship between work life quality and burnout levels in neonatal intensive care nurses. ${ }^{37}$ Similarly, in another study conducted by Kavlu and Pınar on nurses working in emergency services; it is stated that as emotional exhaustion and depersonalization increase, quality of life decreases. $^{27}$ Similarly, in another study 
conducted by Çatak and Bahçecik with nurses, it was stated that the negativities affecting the quality of work life are related to burnout, but the side opportunities provided by the institutions to the employees, practices aimed at improving the quality of work life of the workers such as a supportive work environment and programs to strengthen the employee are noted to increase their loyalty to the institute. ${ }^{38}$ Similar to the above studies, it was found that as the burnout of ICU nurses increases ("emotional exhaustion" and "feeling of falling in personal accomplishment"), their work life quality decreases. Although the above studies investigated the relationship between the quality of work life of nurses and their burnout level, the studies were mostly conducted with correlation tests, which focuses on a general relationship. The fact that burnout level is a factor affecting the quality of work life in this study and when the effect size in the regression model we created is examined, the burnout level has a greater effect on the quality of work life compared to the effect of spiritual wellbeing, which distinguishes this study from the above studies.

\section{CONCLUSION AND RECOMMENDATIONS}

It was found that quality of work life of nurses working in intensive care increased with the increase in their "spiritual wellbeing" levels and a decrease in their burnout levels ("feeling of falling in personal accomplishment" and "emotional exhaustion"). In addition, it was found that the quality of work life of nurses who received spiritual care training was higher than the nurses who did not receive training, and the burnout levels of nurses who received spiritual care training were lower than those who did not receive training.
Thus, it can be suggested that ICU nurses should acquire their knowledge, skills and approaches about spiritual needs not only for patients, patient relatives and team members, but also to increase their social functionality, improve the quality of work life and reduce burnout levels. In addition, it is thought that organizing in-service trainings and seminars can be beneficial in order to increase the spiritual well-being of nurses.

\section{REFERENCES}

1. Terzi, B. and Kaya, N. (2011). "Nursing Care in Intensive Care Patients". Journal of Intensive Care Association, (1), $2-5$.

2. Telci, L. (2002). "How Should Intensive Care Be". Journal of Intensive Care Association, (13), 4-5.

3. Avc1, G.G, Türker, S. Cifçi, M. and Sürücü, S. (2013). "Determining The Workload of Intensive Care Nurses". J Intensive Care Med, 4(21), 3-4.

4. Kavaklı, Ö. Uzun, Ş. and Arslan, F. (2009). "Determining The Professional Behavior of Intensive Care Nurses". Gulhane Medical Journal, 51(3), 168-173.

5. Bostan, S. and Köse, A. (2011). "Nurses' Evaluation of Administrative Services and Work Environments - An Example of A University Hospital". Clinical and Experimental Health Sciences, 1(3), 177-178.

6. Ayaz, S. and Beydağ, K.D. (2014). "Factors Affecting The Quality of Work Life of Nurses: Balıkesir Example". Journal of Health and Nursing Management, 1(2), 60-69.
7. Aksoy, N. M. (2013). "Job Satisfaction and Influencing Factors of Nurses Working in Surgical Units of Three Different Hospitals in A City in The Mediterranean Region", Journal of Education and Research in Nursing, 10(2), 45-53.

8. Şentürk, S. (2014). "Investigation of the Relationship Between Burnout Levels and Sleep Quality of Intensive Care Nurses". Bozok Medical Journal, 4(3), 48-56.

9. Dizer, B. İyigün, E. and Kılıç, S. (2008). "Determining The Burnout Levels of Intensive Care Nurses". Journal of Intensive Care Nursing, 12(1), 1-11.

10. Zaybak, A and Cevik, K. (2015). "Stressors in the Intensive Care Unit: Perceptions of Patients and Nurses". Journal of Critical and Intensive Care, 6(1),4-9.doi: 10.5152/dcbybd.2015.652,

11. Dossey, B.M. (2013). Holistic Nursing: A Handbook for Practice: Jones \& Bartlett Publishers, 20-30.

12. Adegbola, M.A. (2006). Spirituality and Quality of Life in Chronic Illness. Master Thesis, University of Texas, USA 
13. Baldacchino, D.R. (2011). "Teaching on Spiritual Care: The Perceived Impact on Qualified Nurses". Nurse Educ Pract, 11(1), 47-53.

14. Danbolt, L, Engedal, L, Stifoss-Hanssen, H. and Hestad, K. (2014). "Religionspsykologi". Gyldendal Norsk Forlag AS, 1, 397-407.

15. Coyle, J. (2002). "Spirituality and Health: Towards A Framework For Exploring The Relationship Between Spirituality and Health". Journal of advanced nursing, 37(6), 589-597.

16. Koenig, H.G. (2004). "Religion, Spirituality, and Medicine: Research Findings and Implications for Clinical Practice". South Med J, 97(12), 1194-1200.

17. Como, J.M. (2007). "Spiritual Practice: A Literature Review Related To Spiritual Health and Health Outcomes". Holist Nurs Pract, 21(5), 224-236.

18. Cohen, L, Manion L. and Morrison, K. (2013). Research Methods in Education: Routledge.

19. Ekşi, H. and Kardaş, S. (2017). "Spiritual Well-being: Scale Development and Validation". Spiritual Psychology and Counseling, 2(1), 73-88. doi:10.12738/spc.2017.1.00 22

20. Brooks, B and Gawel, S. (2001). "Development and Psychometric Evaluation of The Quality of Nursing Work Life Survey". Dissertation Abstracts International: Section B: Sciences \& Engineering, 62, 1314

21. Sirin, M. (2011). Validity and Reliability Study of Nursing Work Quality of Life Scale. Master Thesis, Atatürk University Institute of Health Sciences, Erzurum.

22. Maslach, C. and Jackson, S.E. (1981). "The mMasurement of Experienced Burnout. Journal of Organizational Behavior", 2(2), 99-113.

23. Ergin, C. (1992). "Adaptation of Burnout and Maslach Burnout Scale in Doctors and Nurses". VII. Ulusal Psikoloji Kongresi, Ankara- Turkey.

24. Durmuş, M. Gerçek, A. and Çiftci, N. (2018). "A Study To Evaluate Nurses' Quality of Life and Burnout Levels". Anemon Muș Alparslan University Journal of Social Sciences, 6(2), 279-286

25. Tunçel, Y.İ. Kaya, M. Kuru, R.N. and Menteş, S. (2014) "Nurses' Burnout Syndrome in Oncology Hospital Intensive Care Unit". Journal of the Turkish Society of Intensive Care, 12(2), 51-56.

26. Yıldırım, A. ve Hacıhasanoğlu, R. (2011). "Quality of Life and Influencing Variables in Healthcare Professionals". J Psychiatr Nurs, 2(2), 61-68.

27. Kavlu, I. and Pinar, R. (2009). "The Effect of Burnout and Job Satisfaction of Nurses Working in Emergency Services on Quality of Life". Turkey Journal of Medical Sciences, 29(6), 1543-1555.

28. Bae, S.J. and Sung, M.H. (2016). "Effects of perception of Death and Spiritual Well-Being on Quality of Life among Nurses in Emergency Room". Journal of East-West Nursing Research, 22(2), 129-137. doi:/10.14370/jewnr.2016.22.2.129

29. Osarrodi, A.A, Golafshani, A. and Akaberi, S.A. (2012) "Relationship Between Spiritual Well-Being and Quality of Life in Nurses". Journal of North Khorasan University of Medical Sciences. 3(4), 88-89.

30. Grant, D. (2004). "Spiritual Interventions: How, When, and Why Nurses Use Them". Holist Nurs Pract, 18(1), 36-41.

31. Pesut, B. (2002). "The Development of Nursing Students' Spirituality and Spiritual Care-Giving". Nurse Educ Today, 22(2), 128-35.

32. Lewis, M.M. (2001). "Spirituality, Counseling, and Elderly: An Introduction To The Spiritual Life Review". Journal of Adult Development, 8(4), 231-240.

33. Musick, M.A, Traphagan, J.W, Koeing, H.G. and Larson, D.B. (2000). "Spirituality in Physical Health and Aging". Journal of Adult Development, 7(2), 73-86.

34. Çetinkaya, B, Altundag, S. and Azak, A. (2007). "Spiritual Care and Nursing". Meandros Medical and Dental Journal, 8(1), 47-50.

35. Musa, A.S, Pevalin, D.J. ve Al Khalaileh, M.A. (2018) "Spiritual Well-being, Depression, and Stress among
Hemodialysis Patients in Jordan". J Holist Nurs, 36(4), 354-365. doi:10.1177/0898010117736686

36. Naimi, E, Eilami, O, Babuei A, ve Rezaei, K. (2020). "The Effect of Religious Intervention Using Prayer For Quality of Life and Psychological Status of Patients With Permanent Pacemaker". Journal of Religion and Health, 59(2), 920-927.

37. Karagöz, E. (2019). Examination of the Relationship Between Work-Life Quality and Burnout Levels of Nurses Working in The Neonatal Intensive Care Unit. Master's Thesis, Hasan Kalyoncu University, Gaziantep.

38. Çatak, T. ve Bahçecik, N. (2015). "Determination of Nurses' Work Life Quality and Influencing Factors". Clinical and Experimental Health Sciences, 5(2), 85-95. doi:10.5455/musbed.20150309010354 